\title{
Bioaccumulation of Heavy Metals in Auchenoglanis occidentalis, Clarias gariepinus and Oreochromis niloticus Tissues in Upper Benue River, Adamawa State, Nigeria.
}

\author{
Edward, A $^{1}$, Abubakar, K.A ${ }^{2}$ Ladu, B.M.B, ${ }^{2}$ Elihu, A $^{1}$ And Umar, $\mathrm{I}^{1}$. \\ ${ }^{I}$ Department of Biological Sciences, Adamawa State University, Mubi-Nigeria \\ ${ }^{2}$ Department of Zoology, Modibbo Adama University of Technology, Yola, Nigeria.
}

\begin{abstract}
Bioaccumulation of heavy metal in fish Auchenoglanis occidentalis,Clarias gariepinus and Oreochromis niloticus) tissues in Upper Benue River was evaluated. Data were collected in four different sites of the river once in month in triplicate from May 2014-October 2015 determination of Heavy metal like $\mathrm{Pb}, \mathrm{Cu}$, $\mathrm{Cd}, \mathrm{Zn}, \mathrm{Cr}$ and Ni using a Buck Scientific 200A model, Atomic Absorption Spectrophotometer. All the Heavy Metals ( $\mathrm{Pb}, \mathrm{Cu}, \mathrm{Cd}, \mathrm{Zn}, \mathrm{Cr}$ and $\mathrm{Ni})$ under investigation were present in measurable amount in fish tissues except Cadmium and Chromium which were below detection level. The mean concentration of Copper ranged between $0.40 \mathrm{mg} / \mathrm{kg}$ to $1.27 \mathrm{mg} / \mathrm{kg}$ which were recorded in A. occidentalis gills and C. gariepinus gills from site A. The mean concentration of Nickel in the fish species tissues ranged from $0.05 \mathrm{mg} / \mathrm{kg}$ to $0.80 \mathrm{mg} / \mathrm{kg}$ which was observed in A. occidentalis gills from Site A and Site C and C. gariepinus gills from Site B in C. The mean concentration of Lead in the gills of some fish species ranged between $0.04 \mathrm{mg} / \mathrm{kg}$ to $1.15 \mathrm{mg} / \mathrm{kg}$ which was observed in C. gariepinus gills from Site D and Site C. The concentration of Zinc ranged between $0.31 \mathrm{mg} / \mathrm{kg}$ in A.occidentalis muscles from Site A to 0.76mg/kg in C.gariepinus liver from Site D. Copper profile in the fish species tissues was gills>liver>muscles. Copper concentration in fish species tissues did not exceed the allowable limits set by WHO. The trend of Ni concentration is gills>muscles>liver. Nickel was observed to be above the permissible limit in the gills of $C$. gariepinus from all the sites and muscle of $O$. niloticus from site $A$. The pattern of the accumulation of lead was gills>liver>muscles. The maximum values of lead obtained in this study exceeded the permissible limit of $0.2 \mathrm{mg} / \mathrm{kg}$. The result of the analysis of Zinc in this study revealed that except A. occidentalis and C. gariepinus gills, all other comparison in variation of Zinc in fish species tissue were significantly different $(P<0.05)$ between sites. The pattern of accumulation was liver $>$ gill $>$ muscles. The concentration of Zinc observed in the tissues of fish species were within the recommended range of $100 \mathrm{mg} / \mathrm{kg}$ for fish food.
\end{abstract}

Keywords:Auchenoglanis occidentalis, Bioaccumulation, Concentration, Clarias gariepinus and Oreochromis niloticus

\section{Introduction}

Heavy metals have been shown to undergo bioaccumulation in the tissue of aquatic organisms. Concern about heavy-metal contamination of fish has been motivated largely by adverse effects on humans, given that consumption of fish is the primary route of heavy metal exposure (Nsikak et al., 2007). Fish accumulate toxic chemicals such as heavy metals directly from water and diet, and contaminant residues may ultimately reach concentrations hundreds or thousands of times above those measured in the water, sediment and food (Goodwin et al., 2003; Labonne et al., 2001; Osman et al., 2007). Several studies (Ademoroti, 1996; Cusimano et al., 1986; Heath, 1987; Allen, 1995; Karthikeyan et al., 2007) have also indicated that fish are able to accumulate and retain heavy metals from their environment depending upon exposure concentration and duration. Adeyeye et al. (1996) also showed that the concentration of metals is a function of fish species as it accumulates more in some fish species than others. Most heavy metals have no beneficial functions to the body and can be highly toxic. High concentration exposure is not necessary to produce a state of toxicity in the body tissue and, overtime, can reach toxic concentration at low levels (Prusty, 1994). Heavy metals belong to the group of elements whose hydro-geochemistry cycles have been greatly accelerated by man. The rapid industrialization, coupled with technological advances in agriculture, has introduced various pollutants (synthetic and organic) into the aquatic ecosystems, which serves as the ultimate sink for most metals (Ogbeibu and Ezeunara, 2002). Heavy metal toxicity can result in damaged or reduced mental and central nervous function, lower energy levels, and damage to blood composition, lungs, kidneys, liver, and other vital organs of the fish. Long-term exposure may result in slowly progressing physical, muscular, and neurological degenerative processes. Various species of fish are mostly used as bio-indicators of heavy metals contamination (Svobodovo et al., 2004). High level of heavy metals has apparent lethal and chronic effects on fishes (Kotze, 1999). Fish have been the most popular choice as test organism because they are presumably the best 
understood organism in the aquatic environment (Buikema et al., 1982) and also due to their importance to man as a protein source (Kim et al., 1996). The aim of this research therefore, is to determine the level of contamination and the bioaccumulation of $\mathrm{Cd}, \mathrm{Cr}, \mathrm{Cu}, \mathrm{Ni}, \mathrm{Pb}$ and Zinc in the most common fish species in Upper Benue River in Adamawa State.

\section{Materials And Methods Study Area}

Adamawa State is located at the North Eastern part of Nigeria. It lies between latitude $7^{\circ}$ and $11^{\circ} \mathrm{N}$ of the equator and between longitude $11^{\circ}$ and $14^{\circ} \mathrm{E}$ of the Greenwich meridian. It has an altitude of 185.9 and covers a land area of about $38,741 \mathrm{~km}$. It shares boundary with Taraba in the south and west, Gombe state in its northwest and Borno state to the north. Adamawa state has and international boundary with Cameroon Republic along its Eastern border. The Benue which is the major river in the state rises from the highlands of Cameroon and flows to the south- ward to join the River Niger at Lokoja River Benue is the main source of water for irrigation, fishing, domestic and industrial purposes in the state. The river is well dissected by network of rivers. The river is approximately $1,400 \mathrm{~km}$ long and it is almost navigable during the summer months (UBRDA, 1985). This study was conducted in the Upper Benue River and the study sites included Njoboliyo (Site A), Boronji (Site B), Jimeta under Bridge (Site C) and Numan Confluence (Site D).

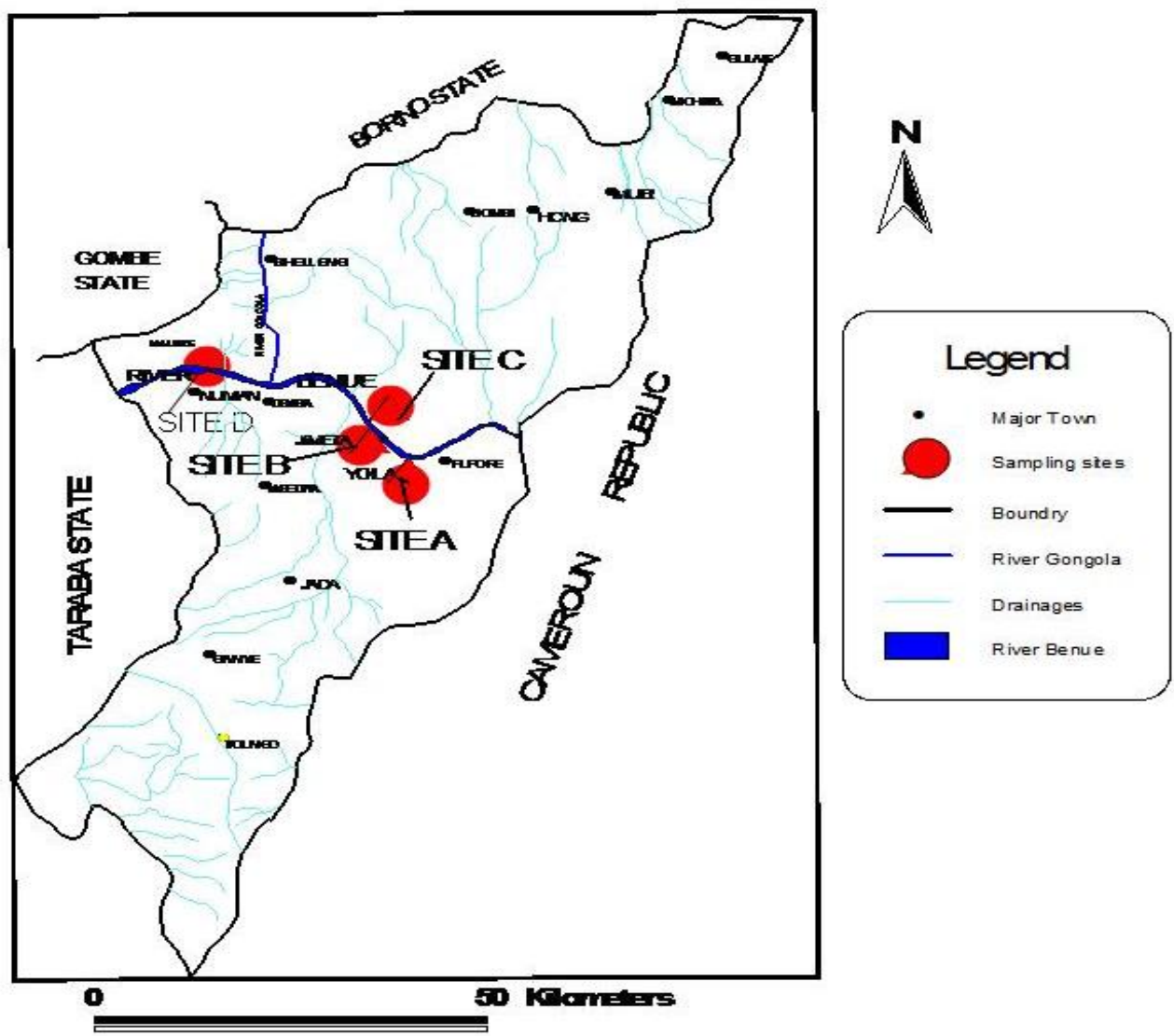

Fig 1: Map of Adamawa State Showing Study Area and Sampling Sites.

\section{Fish Sampling Protocol/Laboratory Measurement}

Fish species of commercial importance (Auchenoglanis occidentalis, Clarias gariepinus and Oreochromis niloticus) were sampled from fish mongers from Upper Benue River. A random composite sampling technique was used without discrepancies for sexes in species. Fish samples were collected in triplicate. Samples were identified taxonomically using standard reference sources (www.fishbase.org). The study was conducted for eighteen months (18) May 2014 to October 2015.

\section{Digestion/ Determination of Heavy Metal in Fish species}

The entire fish samples ((Auchenoglanis occidentalis and Oreochromis niloticus were separated. Scales were removed (for those with scales) and washed with running water before dissecting with sterile scissors to remove gills and livers. These organs were transferred into sterile sample bottles; it was labelled and kept for 
digestion and analysis to determine heavy metals (Novozamsky et al.1983). The flesh, liver and gill of each fish samples were dried at $105^{\circ} \mathrm{C}$ until they reach a constant weight. Each dried sample was grounded, using porcelain mortar and a pestle. The grounded fish organs were transferred to a porcelain basin and put into a Thermion $\mathrm{P}$ muffle furnace at a temperature of $550^{\circ} \mathrm{C}$ for $4 \mathrm{hrs}$. Samples were digested with tri-acid mixture $\left(\mathrm{HNO}_{3}: \mathrm{HClO}_{4} \cdot \mathrm{H}_{2} \mathrm{SO}_{4}=10: 4: 1\right)$ at a rate of $5 \mathrm{ml} /$ per $0.5 \mathrm{~g}$ of sample and were placed on a hot plate at $100^{\circ} \mathrm{C}$ temperature. Determination of Heavy metal like $\mathrm{Cd}, \mathrm{Cu}, \mathrm{Ni}, \mathrm{Pb}$ and Zinc were made directly on each final solution using a Buck Scientific 200A model, Atomic Absorption Spectrophotometer (AAS) and the values obtained was expressed in milligram per kilogram (mg/kg) (APHA 1995, APHA 2005). Procedural blanks were prepared and aspirated along with the analytical samples in order to correct for background absorption. The levels of heavy metals in flesh, gills and liver were evaluated by comparing the statistical mean levels of the metals in the flesh, gills and liver samples.

\section{Statistical Analysis}

Data obtained in this study were analysed using one way analysis of variance (ANOVA) to determine the mean significant variation (at 0.05) in the species tissues and heavy metals in the sampling sites.

\section{Results}

All the Heavy Metals $(\mathrm{Pb}, \mathrm{Cu}, \mathrm{Cd}, \mathrm{Zn}, \mathrm{Cr}$ and $\mathrm{Ni}$ ) under investigation were present in fish organs except Cadmium and Chromium which were below detection level. The Concentration of Copper in tissues of these fish species from different Sites of Upper Benue River is presented in Table 1. The results show that the mean concentration of Copper ranged between $0.40 \mathrm{mg} / \mathrm{kg}$ to $1.27 \mathrm{mg} / \mathrm{kg}$ which were recorded in A. occidentalis gills and C. gariepinus gills from site A. The Concentration of Nickel in tissues of fish species is presented in Table 2. The mean concentration of Nickel in the fish species tissues ranged from $0.05 \mathrm{mg} / \mathrm{kg}$ to $0.80 \mathrm{mg} / \mathrm{kg}$ which was observed in A. occidentalis gills from Site A and Site C and C. gariepinus gills from Site B in $C$. The Concentration of Lead in tissues of fish species is presented in Table 3. The mean concentration of Lead in the gills of some fish species ranged between $0.04 \mathrm{mg} / \mathrm{kg}$ to $1.15 \mathrm{mg} / \mathrm{kg}$ which was observed in C. gariepinus gills from Site $\mathrm{D}$ and Site $\mathrm{C}$. There was a significant variation $(\mathrm{P}<0.05)$ between Sites and fish species. The Concentration of Zinc in tissues of fish species is presented in Table 4. The concentration of Zinc ranged between $0.31 \mathrm{mg} / \mathrm{kg}$ in A.occidentalis muscles from Site A to $0.76 \mathrm{mg} / \mathrm{kg}$ in C.gariepinus liver from Site D.

Table 1: Mean Variation of Copper ( $\mathrm{mg} / \mathrm{kg}$ ) Concentration in the gills, Liver and Muscles of some Fish species from different Sites of Upper Benue River.

\begin{tabular}{|l|l|l|l|l|l|l|l|l|l|l|l|l|}
\hline & \multicolumn{3}{|c|}{ Site A } & \multicolumn{3}{c|}{ Site B } & \multicolumn{3}{c|}{ Site C } & \multicolumn{3}{c|}{ Site D } \\
\hline Fish species & Gills & Liver & Muscles & Gills & Liver & Muscles & Gills & Liver & Muscles & Gills & Liver & Muscles \\
\hline A. ccidentalis & $0.40^{\mathrm{a}}$ & $0.45^{\mathrm{c}}$ & $0.50^{\mathrm{b}}$ & $0.57^{\mathrm{a}}$ & $0.41^{\mathrm{c}}$ & $0.64^{\mathrm{a}}$ & $0.48^{\mathrm{a}}$ & $0.55^{\mathrm{b}}$ & $0.64^{\mathrm{a}}$ & $0.51^{\mathrm{a}}$ & $0.64^{\mathrm{a}}$ & $0.65^{\mathrm{a}}$ \\
\hline C. gariepinus & $1.27^{\mathrm{a}}$ & $0.81^{\mathrm{a}}$ & $0.52^{\mathrm{b}}$ & $0.51^{\mathrm{b}}$ & $0.72^{\mathrm{a}}$ & $0.46^{\mathrm{b}}$ & $0.57^{\mathrm{b}}$ & $0.75^{\mathrm{a}}$ & $0.43^{\mathrm{c}}$ & $0.62^{\mathrm{b}}$ & $0.80^{\mathrm{a}}$ & $0.52^{\mathrm{a}}$ \\
\hline O. niloticus & $0.52^{\mathrm{a}}$ & $0.62^{\mathrm{a}}$ & $0.41^{\mathrm{c}}$ & $0.52^{\mathrm{a}}$ & $0.54^{\mathrm{b}}$ & $0.40^{\mathrm{c}}$ & $0.49^{\mathrm{b}}$ & $0.60^{\mathrm{sb}}$ & $0.50^{\mathrm{b}}$ & $0.41^{\mathrm{b}}$ & $0.62^{\mathrm{b}}$ & $0.60^{\mathrm{a}}$ \\
\hline
\end{tabular}

Means with the same superscript are not significantly $(\mathrm{P}>0.05)$ different from each other

Site A-Njoboliyo

SiteB-Boronji

SiteC-Jimeta Bridge

SiteD-Numan confluence

Table 2: Mean Variation of Nickel (mg/kg) Concentration in the gills, Liver and Muscles of some Fish species in different Sites of Upper Benue River.

\begin{tabular}{|l|l|l|l|l|l|l|l|l|l|l|l|l|}
\hline & \multicolumn{3}{|c|}{ Site A } & \multicolumn{3}{c|}{ Site B } & \multicolumn{3}{c|}{ Site C } & \multicolumn{3}{c|}{ Site D } \\
\hline Fish species & Gills & Liver & Muscles & Gills & Liver & Muscles & Gills & Liver & Muscles & Gills & Liver & Muscles \\
\hline A.ccidentalis & $0.05^{\mathrm{b}}$ & $0.06^{\mathrm{a}}$ & $0.04^{\mathrm{b}}$ & $0.06^{\mathrm{b}}$ & $0.05^{\mathrm{b}}$ & $0.04^{\mathrm{b}}$ & $0.05^{\mathrm{b}}$ & $0.06^{\mathrm{bb}}$ & $0.05^{\mathrm{b}}$ & $0.06^{\mathrm{a}}$ & $0.06^{\mathrm{a}}$ & $0.06^{\mathrm{a}}$ \\
\hline C. gariepinus & $0.79^{\mathrm{a}}$ & $0.06^{\mathrm{a}}$ & $0.06^{\mathrm{b}}$ & $0.80^{\mathrm{a}}$ & $0.07^{\mathrm{a}}$ & $0.32^{\mathrm{a}}$ & $0.66^{\mathrm{b}}$ & $0.07^{\mathrm{a}}$ & $0.26^{\mathrm{a}}$ & $0.76^{\mathrm{a}}$ & $0.07^{\mathrm{a}}$ & $0.27^{\mathrm{a}}$ \\
\hline O. niloticus & $0.07^{\mathrm{c}}$ & $0.20^{\mathrm{a}}$ & $0.79^{\mathrm{a}}$ & $0.08^{\mathrm{bc}}$ & $0.30^{\mathrm{b}}$ & $0.21^{\mathrm{b}}$ & $0.12^{\mathrm{a}}$ & $0.31^{\mathrm{b}}$ & $0.22^{\mathrm{b}}$ & $0.09^{\mathrm{b}}$ & $0.40^{\mathrm{a}}$ & $0.28^{\mathrm{b}}$ \\
\hline
\end{tabular}

Means with the same superscript are not significantly $(\mathrm{P}>0.05)$ different from each other SiteA-Njoboliyo

SiteB-Boronji

SiteC-Jimeta Bridge

SiteD-Numan confluence 
Table 1: Mean Variation of Lead (mg/kg) Concentration in the gills, Liver and Muscles of some Fish species from different Sites of Upper Benue River.

\begin{tabular}{|c|c|c|c|c|c|c|c|c|c|c|c|c|}
\hline & \multicolumn{3}{|c|}{ Site A } & \multicolumn{3}{|l|}{ Site B } & \multicolumn{3}{|l|}{ Site C } & \multicolumn{3}{|c|}{ Site D } \\
\hline Fish species & Gills & Liver & Muscles & Gills & Liver & Muscles & Gills & Liver & Muscles & Gills & Liver & \begin{tabular}{|l} 
Muscles \\
\end{tabular} \\
\hline A.occidentalis & $0.06^{\circ}$ & $0.11^{3}$ & $0.03^{\circ}$ & $0.10^{6 x}$ & $0.09^{2}$ & $0.14^{b}$ & $0.10^{28}$ & $0.13^{2}$ & $0.12^{b}$ & $0.19^{2}$ & $0.13^{2}$ & $0.22^{2}$ \\
\hline C.gariepinus & $0.11^{1}$ & $0.08^{26}$ & $0.12^{2}$ & $0.09^{b}$ & $0.03^{b}$ & $0.04^{\circ}$ & $1.15^{\mathrm{a}}$ & $0.10^{2}$ & $0.07^{6}$ & $0.04^{b}$ & $0.07^{26}$ & $0.06^{x}$ \\
\hline O.niloticus & $0.31^{\mathrm{b}}$ & $0.21^{b}$ & $0.21^{\mathrm{a}}$ & $0.38^{b}$ & $0.14^{\circ}$ & $0.12^{b}$ & $0.47^{b}$ & $0.23^{b}$ & $0.20^{2}$ & $0.72^{2}$ & $0.27^{\mathrm{a}}$ & $0.14^{45}$ \\
\hline
\end{tabular}

Means with the same superscript are not significantly $(\mathrm{P}>0.05)$ different from each other

SiteA-Njoboliyo

SiteB-Boronji

SiteC-Jimeta Bridge

SiteD-Numan confluence

Table 4: Mean Variation of Zinc ( $\mathrm{mg} / \mathrm{kg}$ ) Concentration in the gills, Liver and Muscles of some Fish species in different Sites of Upper Benue River.

\begin{tabular}{|l|l|l|l|l|l|l|l|l|l|l|l|l|}
\hline & \multicolumn{3}{|l|}{ Site A } & \multicolumn{3}{l|}{ Site B } & \multicolumn{3}{l|}{ Site C } & \multicolumn{1}{l|}{} \\
\hline Fish species & Gills & Liver & Muscles & Gill & Liver & Muscles & Gills & Liver & Muscles & Gills & Liver & Muscles \\
\hline A.occidentalis & $0.38^{\mathrm{a}}$ & $0.32^{\mathrm{b}}$ & $0.31^{\mathrm{b}}$ & $0.35^{\mathrm{a}}$ & $0.38^{\mathrm{ab}}$ & $0.33^{\mathrm{ab}}$ & $0.33^{\mathrm{a}}$ & $0.41^{\mathrm{a}}$ & $0.36^{\mathrm{ab}}$ & $0.37^{\mathrm{b}}$ & $0.36^{\mathrm{ab}}$ & $0.37^{\mathrm{a}}$ \\
\hline C.gariepinus & $0.40^{\mathrm{a}}$ & $0.63^{\mathrm{b}}$ & $0.30^{\mathrm{b}}$ & $0.41^{\mathrm{a}}$ & $0.64^{\mathrm{b}}$ & $0.44^{\mathrm{a}}$ & $0.45^{\mathrm{a}}$ & $0.74^{\mathrm{a}}$ & $0.35^{\mathrm{b}}$ & $0.45^{\mathrm{a}}$ & $0.76^{\mathrm{a}}$ & $0.41^{\mathrm{a}}$ \\
\hline O.niloticus & $0.50^{\mathrm{bc}}$ & $0.62^{\mathrm{b}}$ & $0.34^{\mathrm{b}}$ & $0.53^{\mathrm{b}}$ & $0.61^{\mathrm{b}}$ & $0.39^{\mathrm{b}}$ & $0.45^{\mathrm{c}}$ & $0.65^{\mathrm{a}}$ & $0.39^{\mathrm{b}}$ & $0.63^{\mathrm{a}}$ & $0.69^{\mathrm{a}}$ & $0.46^{\mathrm{a}}$ \\
\hline
\end{tabular}

Means with the same superscript are not significantly $(\mathrm{P}>0.05)$ different from each other

SiteA-Njoboliyo

SiteB-Boronji

SiteC-Jimeta Bridge

SiteD-Numan confluence

\section{Discussion}

The results of the current study showed a significant variation in the accumulation of metals in the different tissue of different fish species, which is principally dependent on the bioavailability of metal concentration in the aquatic habitat (Peakal and Burgar, 2003, Marcovecchio, 2004). However, the highest Copper concentration in this study did not exceed the allowable limit for fish food. FAO (1983) gave a maximum allowable limit Copper in fish food as $30 \mathrm{mg} / \mathrm{kg}$. Generally, the result indicated that Copper value was higher in gills especially that of $C$. gariepinus than liver and muscles of all the fish species which was reported in Site A. The reason could be due to the fact that gills which are in direct contact with water might have accumulated more of Copper than any organ. This is in line with the report of Nuessey et al. (2001), who reported that gills of fishes accumulate more amounts of heavy metals than other tissues due to their intimate contact with the aquatic environment. Nickel was observed to be above the permissible limit in the gills of $C$. gariepinus from all the sites and muscle of $O$. niloticus from site A as recommended by (WHO, 2003; FEPA, 2003 ) in fish food. The trend of Nickel concentration in fish organ in this study was gills>muscles>liver. This study corroborates the assertion that gills are the main position of entry for the dissolved metals as a result they present the target for the toxic action of metals (Olsson et al, 1998). A significant variation was observed in Lead concentration in the organs of fish species. The highest Lead was observed in gills of C. gariepinus in site C, liver of $O$. niloticus recorded the highest lead from site $\mathrm{D}$ and muscles of A. occidentalis obtained the highest Lead in site $\mathrm{D}$. The highest values of Lead obtained in this study in fish tissue exceeded the maximum recommended limit of $0.2 \mathrm{mg} / \mathrm{kg}$ (WHO, 2003; FEPA, 2003; and FAO 1983) in fish food. The pattern of accumulation of Lead in this study was gills>liver>muscles. Generally, the highest Lead was observed in gills of C.gariepinus in site C. The reason for the high level of Lead in the gills may be due to adsorption of heavy metals to the gills surfaces and dependent on the availability of protein to which Lead may bind. Ikem et al, (2001) reported that high levels of metals in fish species relative to other tissues may be attributed to the affinity or strong coordination of metallothionein protein with this element. The result of the analysis of Zinc in this study revealed that, with the exception of A. occidentalis and C. gariepinus gills, all other comparison in the variation of $\mathrm{Zn}$ in fish species tissues were significantly different between sites. The concentration of $\mathrm{Zn}$ observed in the current study was within the permissible limit of $100 \mathrm{mg} / \mathrm{kg}$ for fish food set by (FAO, 1992; WHO, 2003). The trend of the accumulation of $\mathrm{Zn}$ in the study was liver>gills $>$ muscles. This is in line with the result obtained by Akan, et al. (2009) who reported the same trend of bioaccumulation of heavy metal of six fresh water fishes from Lake Chad. In general, accumulation of the heavy metals (total mean) analysed in the sampled fishes was of the following trend: C. gariepinus $>O$. niloticus $>A$. occidentalis and the pattern of distribution is $\mathrm{Cu}>\mathrm{Pb}>$ Nickel $>\mathrm{Zn}$ for all the fish species. This showed that the accumulation of the heavy metals was species-related. 


\section{Conclusion}

All the heavy metals present in fish tissues were within the recommended limit for fish food except Nickel and Lead which was slightly high in some tissues of $C$. gariepinus and $O$. niloticus and was outside the recommended range when compared with the maximum recommended limits.

\section{Acknowledgement}

The authors would like to acknowledge Mr Raii Mohammed Department of Biochemistry, Modibbo Adama University of Technology, Yola, Nigeria and Mr Saminu Abdulkarim Department of Chemistry. Adamawa State University, Mubi -Nigeria for their laboratory assistance.

\section{References}

[1]. Ademoroti, C.M.A (1996). Environmental Chemistry and Toxicology, Foludex Press Ltd. Ibadan pp. 171-204.

[2]. Adeyeye, E.I., Akinyugha, R.J., Febosi, M.E. and Tenabe, V.O. (1996). Determination of some metals in Clarias gariepinus (Cuvier and Valenciemes), Cyprinus carpio L) and Oreochromis niloticus (L) fishes in a polyculture fresh water pond and their environment. Aquacut, 47, 205- 214

[3]. Akan, J.C., F.I. Abdulrahman, O.A. Sodipo\& P.I. Akandu. 2009. Bioaccumulation of some heavy metals of six fresh water fishes caught from lake chad in DoronBuhari, Maiduguri, Borno State State Nigeria. Nig. J. app. Sci. Environ. Manag. 4:103-11.

[4]. Allen, P. (1995): Chronic Accumulation of Cadmium in the edible Tissues of Oreochromis aurus (Steindachner): Modification by Mercury and Lead. Arch. Environ. Contam.Toxicol., 29, 8-14.APHA (1995). Standard Methods for the Examination of Water and Waste Water. (15th Edition) Washington, D.C.

[5]. APHA (1995).Standard Methods for the Examination of water and waste water. $21^{\text {st }}$ Edn. Washington, D. C.

[6]. APHA. (2005). Standard Methods for the Examination of Water and Waste- Water. $21^{\text {st }}$ Edn. Washington, D.C.

[7]. Buikema, A. L. (Jr), Niederlehner, B. R. and Cairns, J. (Jr) (1982): Biological Monitoring: Part IV - Toxicity Testing. Water Res. 16: 239-262.

[8]. Cusimano, R.F., Brakke, D. F. and Chapman, G.A. (1986): Effects of pH on the toxicity of Cadmium, Copper and Zinc to steelhead trout (salmogairdneri). Can. J. Fish Aquat.Sci., in some fish species from Azuabic Creek in the Bonny Estuary, Nigeria. African J. Biotech., 7, 63-64.

[9]. FAO, (1983): Compilation of legal limits for hazardous substances in fish fishery products. FAO Fishery Circular, No. 464, pp5100.

[10]. FEPA, (2003): Guideline and Standards for Environmental pollution and control in Nigeria. Federal Environmental protection Agency, Nigeria

[11]. Food and Agriculture Organization (FAO). (1992). Report of third session of working party on pollution and fisheries, Accra, Ghana, 25-29 $9^{\text {th }}$ Nov., 1991 .

[12]. Goodwin, T. H., Young, A., Holmes, M., Old, G., Hewitt, N., Leeks, G.,Packman, J. and Smith, B. (2003): "The Temporal and Spatial Variability of Sediment Transport and Yields within the Bradford Beck Catchment, West Yorkshire," Science of the Total Environment, Vol. 314, pp.475-494.

[13]. Heath, A.G. (1987): Water Pollution and Physiology. CRC press Inc., Boca Raton. 145 pp.

[14]. Karthikeyan, S., Palaniappan, P.L.R.M. and Sabhanayakan, S. (2007): Influence of pH and water hardness upon Nickel accumulation in edible fish Cirrhinus mrigala. J. Environ. Biol.,28,484-492

[15]. Kime, D.E., Ebrahimi, M., Nysten, K., Roelants, I., Rurangwa, E., Moore, H.D.M. and Ollevier, F. (1996): Use of computer assisted sperm analysis (CASA) for monitoring the effects of pollution on sperm quality of fish, application to the effects of heavy metals. Aquatic Toxicology. 36: 223-237.

[16]. Kotze, P; Preez, H. H and Van Vuren, J. H. (1999). Bioaccumulation of Copper and Zinc in Oreochromis mossambicus and Clarias gariepinus, from the Olifants River, Mpumalanga, South Africa," Water SA, Vol. 25, No. 1, pp. 99-110.

[17]. Labonne, M., Basin, S., Othman, D. and Luck, J. (2001): "Lead Isotopes in Muscels as Tracers of Metal Sources and Water Movements in a Lagoon (Thau Basin, S. France),'Chemical Geology, Vol. 181, No. 1-4, pp. 181-191.

[18]. Marcovecchio, J.E. (2004). The use of Micropogoniasfurnieri and Mugillizar as bioindicators of heavy metals in La Plato river estuary, Argentina Science of the total environment. 323:219-226

[19]. Novozamsky, I., Houba, V.J.G., van Eck, R., van Vark, W. (1983): A novel digestion technique for multi-element plant analysis. Communications in Soil Science and Plant Analysis 14, 239-248.

[20]. Nsikak, U.B., P.E. Joseph, B.W. Akan \& E.B. David. 2007. Mercury accumulation in fishes from tropical aquatic ecosystems in the Niger Delta, Nigeria. Current Science 92: 781-785.

[21]. Nussey, G. (2000) "Bioaccumulation of Chromium, Manganese, Nickel and Lead in the Tissues of the Moggel, labeoumbratus (Cyprinidae), from Witbank Dam, mpumalanga," water SA, Vol. 26, No. 2, 2000, pp. 269-284.

[22]. Ogbeibu, A.E. \& P.U. Ezeunara. 2002. Ecological impactof brewery Effluent on Ikpoba River using the fish communities as bio indicators. J. Agua. Res. 17:35-44.

[23]. Olsson, P.E, Kling,P, Hogstrand,C. (1998). Mechanism of of Heavy Metal accumulation and Toxicity in fish, In: Langstone W.J., Babianno, M.J (Eds), Metabolism in aquatic environment, Chapman and Hall, London, Pp 321-350.

[24]. Osman, A., Wuertz, S., Mekkawy, I., Exner, H, And Kirschbaum, F. (2007)."Lead Induced Malformations in Embryos of the African Catfish Clarias Gariepinus (Burchell, 1822), Environmental Toxicology, Vol. 22, No. 4, Pp. 375-389.

[25]. Peakall D, Burger J. Methodology for Assessing Exposure to metals: Speciation Bioavailability of metals, and Ecological Host Factors. Ecotoxicol Environ Saf. 2003; 56(1): 110-121.

[26]. Prusty, A.W. 1994. The use of fish in monitoring water pollution. Tour Biotech. p.4-Svobodova, Z. Celechovska, O. Kolara, J. Randak,T. and V. Zlabek, (2004). "Assessment of Metal Contamination in the Upper Reaches of the Ticha Orlice River," Czech Journal of Animal Science, Vol. 49, No. 4, 2004, pp. 458-641.

[27]. Upper Benue River Basin Development Authority (UBRBDA) (1985).

[28]. World Health Organization (WHO). (2004). Heavy Metal regulation: Legal notices no 66www.Discoverlife.2008 